\title{
Postnatal characterization of cells in the accessory olfactory bulb of wild type and reeler mice
}

\author{
Eduardo Martín-López, Rebeca Corona ${ }^{\dagger}$ and Laura López-Mascaraque *
}

Department of Molecular, Cellular, and Developmental Neurobiology, Instituto Cajal (CSIC), Madrid, Spain

Edited by:

Jorge A. Larriva-Sahd, Universidad Nacional Autónoma de México

México

Reviewed by:

Alino Martinez-Marcos, Universidad de Castilla, Spain

Alfredo Varela-Echavarria, Instituto de Neurobiología - UNAM, México

*Correspondence:

Laura López-Mascaraque, Instituto Cajal (CSIC), Avenida del Doctor

Arce, 37, 28002 Madrid, Spain.

e-mail: mascaraque@cajal.csic.es

${ }^{\dagger}$ Present Address:

Department of Behavioral and

Cognitive Neurobiology, Instituto de Neurobiología (UNAM), Queretaro, Mexico.

\begin{abstract}
Olfaction is the most relevant chemosensory sense of the rodents. General odors are primarily detected by the main olfactory system while most pheromonal signals are received by the accessory olfactory system. The first relay in the brain occurs in the olfactory bulb, which is subdivided in the main and accessory olfactory bulb (MOB/AOB). Given that the cell generation time is different between $A O B$ and $M O B$, and the cell characterization of $A O B$ remains limited, the goal of this work was first, the definition of the layering of $\mathrm{AOB} / \mathrm{MOB}$ and second, the determination of cellular phenotypes in the $A O B$ in a time window corresponding to the early postnatal development. Moreover, since reelin (Reln) deficiency has been related to olfactory learning deficits, we analyzed reeler mice. First, we compared the layering between $A O B$ and $M O B$ at early embryonic stages. Then, cell phenotypes were established using specific neuronal and glial markers as well as the Reln adaptor protein Dab1 to analyse differences in both genetic backgrounds. There was no apparent difference in the cell phenotypes among $\mathrm{AOB}$ and $\mathrm{MOB}$ or between wild type $(w t)$ and reeler animals. However, a disruption in the granular cell layer of reeler with respect to wt mice was observed. In conclusion, the AOB in Reln-deficient mice showed similar neuronal and glial cell types being only affected the organization of granular neurons.
\end{abstract}

Keywords: main olfactory bulb, reelin, granular cells layering, postnatal development, cell characterization

\section{INTRODUCTION}

A wide number of socio-sexual behaviors in mammals depend upon the environment chemosensory signals. In rodents, the olfactory system appears to be the most important for the perception of chemical signals that allows the organism get the information from the environment. Olfaction starts with the direct interaction of the odorant molecules with the olfactory receptors of the sensory neurons that send their axons up to the olfactory bulb, step that constitutes the first relay of the olfactory information to the central nervous system. Olfactory bulb has been divided in two different but complementary systems, the main and accessory olfactory systems. They differ in their anatomy, projections, and function. Sensory receptors of the main olfactory system are a large family of receptors located on the olfactory sensory neurons (OSNs) sited in the main olfactory epithelium and projecting into the main olfactory bulb (MOB). For the accessory olfactory system, the receptors are located in the vomeronasal organ and project to the accessory olfactory bulb (AOB). Both $\mathrm{MOB}$ and $\mathrm{AOB}$ are an interface between the OSN and higher olfactory centers, and their position in olfaction is often compared to the thalamus in other sensory systems (Shepherd, 2005). These two anatomically distinct olfactory systems were described as functionally distinct, with the main olfactory epithelium detecting volatile odorants and the vomeronasal organ detecting non-volatile pheromones through direct physical contact with the source (Mori et al., 2000). However, OSNs are also sensitive to pheromones present in mouse urine (Restrepo et al., 2004) and the simultaneous presentation of odorants and pheromones to the same animal provoke responses from both MOB and AOB (Luo et al., 2003; Xu et al., 2005). This suggests that these two systems might not be as functionally distinct as was originally thought (Meredith, 1991; Baum and Kelliher, 2009).

Molecular and functional characteristics of these structures have been described (Lopez-Mascaraque and De Castro, 2002; for reviews Blanchart and Lopez-Mascaraque, 2011) but additional information, particularly regarding the $\mathrm{AOB}$ development, is still necessary to define the complete form and function of this system. On other hand, it is widely known that layered structures in the brain use Reelin (Reln) as a key molecule for proper neuronal positioning (Honda et al., 2011) and it appears to be relevant during the MOB layering (Wyss et al., 1980; Martin-Lopez et al., 2011). Reln exerts its actions through the Dab1 intracellular adaptor protein (Howell et al., 1997; Rice et al., 1998), molecule which is strongly expressed in the MOB (Martin-Lopez et al., 2011). In addition, Reln acts as detachment signal for chain-migrating neuroblasts which promotes their radial migration into the olfactory bulb (Hack et al., 2002). During OB development, Reln mRNA begins to be expressed at E10 in the mitral cells and it is restricted to mitral and periglomerular cells at postnatal ages (D'Arcangelo et al., 1995; Schiffmann et al., 1997; Alcantara et al., 1998). In the Reln deficient mice (reeler), despite alterations in MOB layering (Wyss et al., 1980; Hack et al., 2002), expression patterns of Dab1 is undistinguishable between the MOB of wild type (wt) and reeler mice (Martin-Lopez et al., 2011). Thus, regardless of 
the information known about Reln in the MOB, there is still a lack of information on the effects of this protein on the precise final layering of the AOB.

Consequently, the goals of this work were first, to clarify the layering of $\mathrm{AOB}$ from early embryonic stages to late postnatal development and then to compare the AOB/MOB layering. Second, we addressed the spatio-temporal, molecular, and phenotypical characterization of $\mathrm{AOB}$ cells comparing wt with reeler mice during early postnatal development. For this purpose, we characterized the $\mathrm{AOB}$ cell populations by using specific markers against mature neurons (MAP2a,b, and NeuN), some periglomerular cells ( $\mathrm{CB}$ and $\mathrm{TH})$, radial glia (RC2), astrocytes (GFAP), oligodendrocytes (RIP), and molecules involved in layering processes like Reln and its adaptor protein Dab1.

\section{MATERIALS AND METHODS}

Wild type C57 ( $w t$ ) and Reln mutant (reeler) mice from postnatal stages P0, P3, P7, and P15, were obtained from the Cajal Institute mouse breeding facility. Genotyping of reeler mice was performed by PCR analysis of genomic DNA. Experiments were performed in accordance with procedures approved by the Spanish Research Council Bioethics Committee. For animal experimentation, we followed the ethical principles dictated by the European Commission (Directive 2010/63/UE and 86/609/CEE) for use of laboratory animals and Spanish regulation (RD 1201/2003 and ley 32/2007).

\section{NISSL STAINING}

Embryonic Nissl staining sagittal sections were obtained from fixed paraformaldehyde thionin-stained sections (Jimenez et al., 2000). Postnatal sagittal sections at $20 \mu \mathrm{m}$ (see below for Procedure) were stained with acid thionin ( $\mathrm{pH} 4.5$ ) for $1 \mathrm{~min}$ and washed with water. Sections were dehydrated with graded ethanol and xylol, and coverslipped with DPX mountant.

\section{IMMUNOHISTOCHEMISTRY}

Mice ( $n=5$ per each age and strain) of either sex were deeply anesthetized by hypothermia (P0 and P3) or with i.p. equithesin at lethal dose (P7 and P15) and transcardially perfused with heparinized saline followed by $4 \%$ of paraformaldehyde $(1 \mathrm{ml} / \mathrm{g})$ in $0.1 \mathrm{M}$ phosphate-buffered $(\mathrm{PB})$. Brains were removed and post-fixed in the same fixative, cryoprotected with 30\% sucrose in PB, and sagittally sectioned at $20 \mu \mathrm{m}$ in a TC1900 cryostat (Leica). Sections were frozen until their use in immunostaining.

Table 1 | List of antibodies.

\begin{tabular}{|c|c|c|c|c|}
\hline Primary antibody & Clone & Product company & Dilution & Cell type marked \\
\hline Calbindin (CB) & 300 & Swant & $1: 5000$ & Localizes D-28k CB which occur in a subset of neurons \\
\hline Dab1 & Polyclonal & Sigma-Aldrich (D1569) & $1: 1000$ & A subset of cell types \\
\hline GFAP & GA5 & Chemicon & $1: 1000$ & Glial fibrillary acidic protein expressed in astrocytes \\
\hline Map2a,b & AP20 & Chemicon & $1: 1000$ & Microtubule associated protein-2 expressed in mature neurons \\
\hline NeuN & A60 & Chemicon & $1: 1000$ & Neuronal nuclei protein \\
\hline $\mathrm{RC} 2$ & $\mathrm{RC} 2$ & Hybridoma-Bank & $1: 500$ & A $295 \mathrm{kDa}$ intermediate filament protein present in radial glial cells \\
\hline RIP & NS-1 & Chemicon & $1: 1000$ & Detects non-myelin and myelin oligodendrocytes \\
\hline Reelin & G10 & Chemicon & $1: 1000$ & Detects reelin expressed in a subset of neurons \\
\hline $\mathrm{TH}$ & LNC1 & Chemicon & $1: 1000$ & Detects tyrosine hydroxylase enzyme expressed by dopaminergic neurons \\
\hline
\end{tabular}

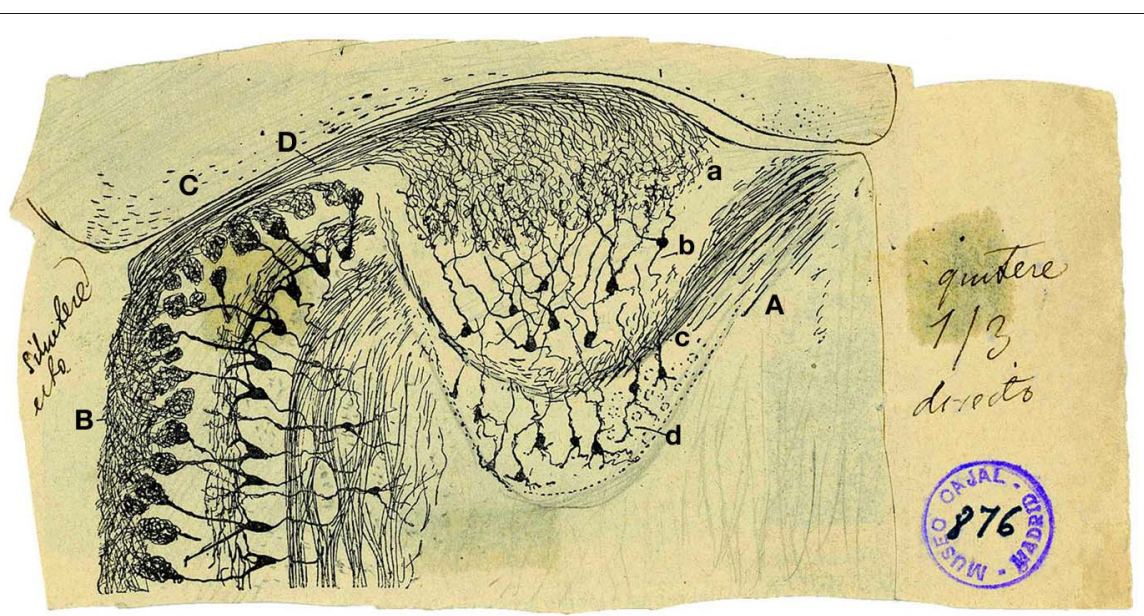

FIGURE 1 | Reproduction of an original Cajal drawing from a Golgi stained horizontal section from 20-days-old mice, showing some morphological features of the accessory and main olfactory bulb.
(A) Accessory olfactory bulb; (B) Main olfactory bulb; (C) Cortex; (D) Vomeronasal nerve; (a) Glomerular layer; (b) mitral/tufted layer; (c) Plane of the lateral olfactory tract; (d) granule cells [Ramon y Cajal (1901)]. 
Frozen sections were air dried, permeabilized with saline $\mathrm{PB}$ (PBS) plus 0.1\% TritonX100 (PBST) (Sigma-Aldrich Co.) and by microwave heating in $10 \mathrm{mM}$ citrate buffer, $\mathrm{pH}$ 6, for three boiling cycles of $5 \mathrm{~min}$ each to unmask the antigen. Unspecific binding of antibodies was blocked with PBST supplemented with $10 \%$ normal goat serum (NGS) plus $0.1 \%$ bovine serum albumin for $1 \mathrm{~h}$ at room temperature (RT) and then incubated overnight at $4^{\circ} \mathrm{C}$ using specific primary antibodies diluted in PBST plus 1\% NGS (Table 1). Antibody binding was detected with the following secondary antibodies, diluted 1:1000 in PBST: Alexa 488/568 goat anti-rabbit IgG and Alexa 568 goat anti-mouse IgG (Molecular Probes-Invitrogen). The radial glia antibody (RC2) was detected by incubating $2 \mathrm{~h}$ at RT with biotin conjugated goat anti-mouse IgM (Jackson Immunoresearch) and then incubated

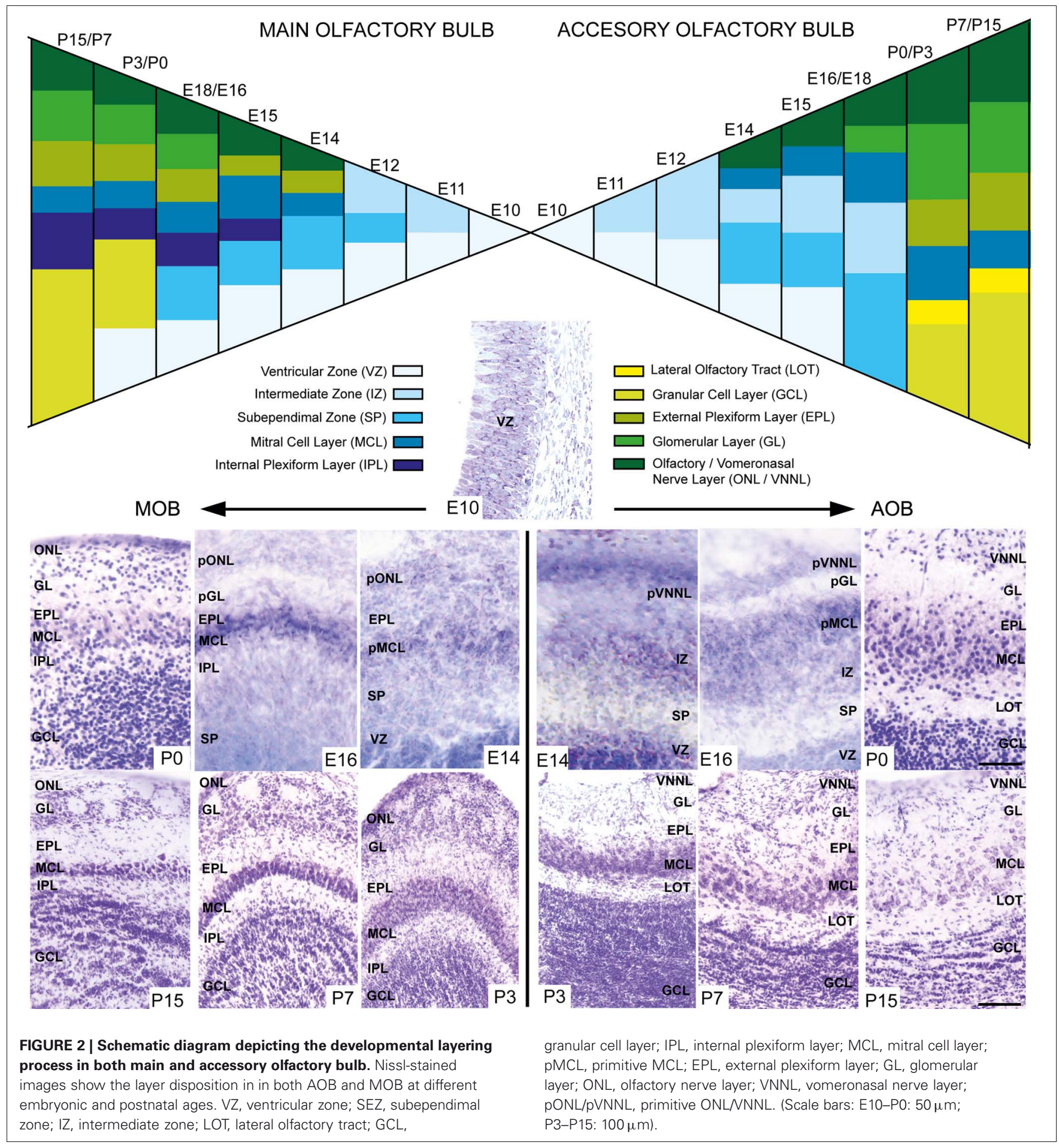


$1 \mathrm{~h}$ at RT with Alexa 568 conjugated streptavidin (Molecular Probes-Invitrogen). Nuclei were counterstained with Hoechst ( $1 \mu \mathrm{g} / \mathrm{ml}$, Sigma-Aldrich Co). Staining was visualized using a confocal microscope TS5 (Leica).

\section{RESULTS}

\section{A BRIEF DESCRIPTION OF THE ACCESSORY OLFACTORY BULB STRUCTURE AND ORGANIZATION}

The AOB is a lens-shaped structure, much smaller than the MOB, delimited rostrally and ventrally by the MOB, caudally by the accessory olfactory nucleus and dorsally by the prefrontal cortex. Figure 1 shows an original drawing by Cajal (Ramon y Cajal, 1901) revealing the structure and layers of both the AOB (Figure 1A) and a region of the MOB (Figure 1B) in a horizontal section where is included the vomeronasal nerve (Figure 1D). Cajal divided the AOB into four layers: the glomerular layer (Figure 1Aa, GL), mitral/tufted (Figure 1Ab, M/T), lateral olfactory tract (Figure 1Ac, LOT), and granule cell layer (Figure 1Ad, GCL). This layered structure is similar to MOB although they display some differences previously reviewed (Meisami and Bhatnagar, 1998) and highlighted by Larriva-Sahd (2008).

\section{DEVELOPMENTAL TIMING OF AOB vs. MOB LAYERING}

During embryonic brain development, layering of the AOB is slightly different from that of the MOB since cell differentiation occurs at different ages in both structures. To address this issue, we performed a cytoarchitectonic study to compare the formation of the different layers in both $\mathrm{AOB}$ and $\mathrm{MOB}$ (Figure 2). Both bulbs emerged from a neuroepithelium located in the rostralmost part of the telencephalic vesicle (Figure 2, E10). One day later (E11) the layering begins when an intermediate zone (IZ) is segregated from the ventricular zone (VZ). Next, a new layer intercalates between $\mathrm{VZ}$ and IZ forming the subependimal zone (SP) in the prospective MOB while in the AOB it occurs at E13. Although the first olfactory sensory axons reach the surface of the prospective MOB at E12 (Blanchart et al., 2006, 2008), the primitive olfactory (pONL) and vomeronasal nerve ( $\mathrm{pVNNL}$ ) layers are visible at E13. At E14 in both structures emerges the primitive mitral cell layer (pMCL, Figure 2). At E15/16 a prospective glomerular layer becomes evident in both AOB/MOB (pGL, Figure 2). From E17 onwards the layering is completed and in the first postnatal days ( $\mathrm{P} 0-\mathrm{P} 3)$ the granule cell layer becomes thicker and visible in both bulbs. Complete refinement of layering organization is achieved at P7, although periglomerular and granule cells are constantly added to these local circuits in adult brains (Altman, 1969; Lois and Alvarez-Buylla, 1994; Peretto et al., 2001; Oboti et al., 2009).

\section{MOLECULAR CHARACTERIZATION OF THE AOB IN wt AND reeler POSTNATAL MICE}

Since the disabled 1 (Dab1) protein is essential for Reln signaling during brain development and is expressed thorough all $\mathrm{MOB}$ layers at early postnatal ages (Martin-Lopez et al., 2011), we analyzed the relationship between the expression of Reln and Dab1 in the AOB of both $w t$ and reeler mice (Figure 3 ). In the AOB, Reln was markedly expressed in the cytoplasm of mitral and some periglomerular cells at each postnatal ages (Figures 3A,C,E,G) as occurs in the MOB (Martin-Lopez et al., 2011). By contrast, Dab1 protein was expressed in most neuronal cells along the AOB layers in both cytoplasm and nuclear cell compartments in both strains (Figure 3), although the pattern of protein location changed from $\mathrm{P} 0$ to P15. Thus, at P0, strong Dab1 labeling was detected in
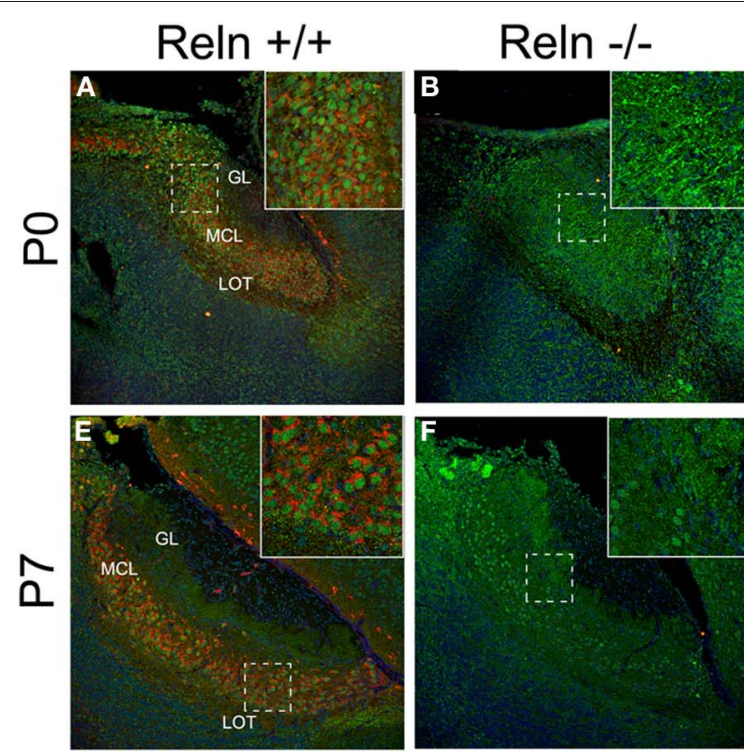

FIGURE 3 | Expression of Reln and its adaptor protein Dab1 in the accessory olfactory bulb of wild type and reeler mice. Reln (red) is strongly expressed by mitral and periglomerular cells at P0, P3, P7, and P15 (A,C,E,G). Dab1 expression (green) is mainly located in the nuclei of the MCL and GL cells as well as in the fibers located
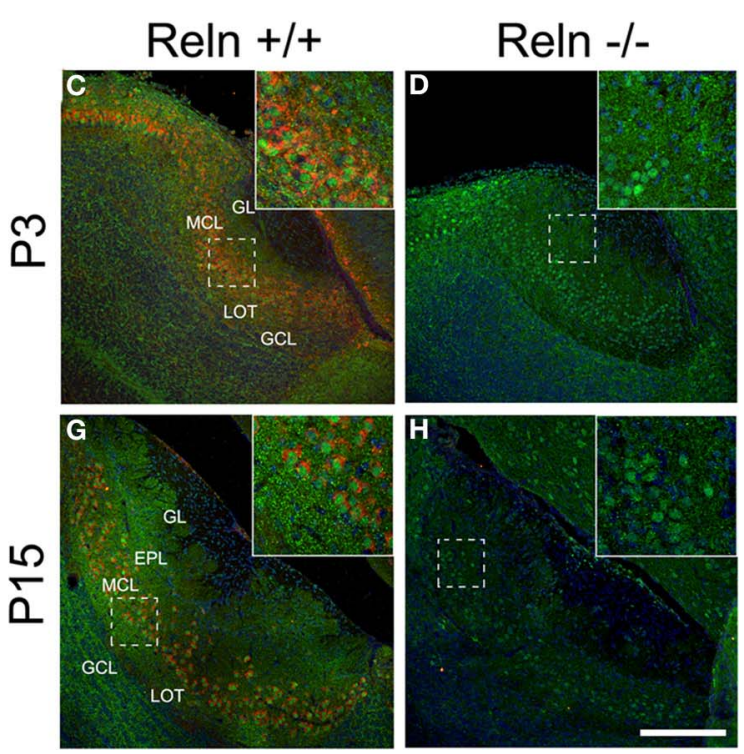

throughout GL, EPL, IPL, and GCL in both strains (A-H). Nuclei were counterstained with Hoechst (blue). LOT, lateral olfactory tract; GCL, granular cell layer; IPL, internal plexiform layer; $M C L$, mitral cell layer; EPL, external plexiform layer; GL, glomerular layer (Scale bar: $200 \mu \mathrm{m})$. 
both nuclei of mitral/periglomerular cells and in thin cellular processes throughout all AOB layers (Figures 3A,B). These cellular processes lost the Dab1 expression at P3 (Figures 3C,D), while it was maintained as a dotted pattern just in the cell bodies of GCL, MCL, and EPL (Figures 3E-H). However, nuclear labeling was intense along all postnatal ages in mitral and periglomerular cells. Dab1 expression pattern was similar between $w t$ and reeler mice.

Further, we analyzed the neuronal and glial AOB phenotypes and whether the absence of Reln (reeler) produced a change in the neurochemical phenotype of those cells. First, we characterized the $\mathrm{AOB}$ neuronal phenotypes at different postnatal ages (P0, P3, P7, and P15) by using Map2a,b and NeuN as markers for mature neurons and $\mathrm{CB}$ and $\mathrm{TH}$ as markers for periglomerular cells (Figure 4). Map2a,b protein was strongly expressed in cell bodies and fibers of mature neurons in the GL, EPL, and MCL at all selected ages (Figures 4A,B,G,H,M,N,S,T). On the other hand, NeuN was mainly expressed in granular cells in all ages and in many periglomerular cells from P7
(Figure 4, NeuN). Thus, at P0-P7, NeuN is expressed in some granular cells, which appeared scattered throughout the GCL in both strains (Figures 4C,D,I,J,O,P). At P15, NeuN labeling increases in granular cells that were clustered together in small groups. Those groups were aligned and parallel to the lateral olfactory tract (LOT) in the $w t$ (Figure $4 \mathbf{U}$, arrows) while this arrangement was disrupted in reeler (Figure $\mathbf{4 V}$, arrows). Periglomerular cells expressing $\mathrm{TH}$ were confined to the edges of the AOB glomeruli at all postnatal ages (Figure 4, TH) and no differences were detected between $w t$ (Figures $4 \mathbf{E}, \mathbf{K}, \mathbf{Q}, \mathbf{W}$ ) and reeler mice (Figures $\mathbf{4 F}, \mathbf{L}, \mathbf{R}, \mathbf{X}$ ). With respect to $\mathrm{CB}$ cells just a low expression was present in the $\mathrm{AOB}$ (data not shown).

The AOB glial phenotypes were studied using markers for radial glial cells (RC2), astrocytes (GFAP) and oligodendrocytes (RIP). A large number of processes positive for RC2 were observed at $\mathrm{P} 0$ along the $\mathrm{AOB}$ (Figures 5A,B), and then decreased at P3 (Figures 5G,H) to be absent at P7-P15 (Figures 5M,N,S,T). Moreover, from P3 onwards RC2 protein was also located in stellate shaped-cell bodies throughout all

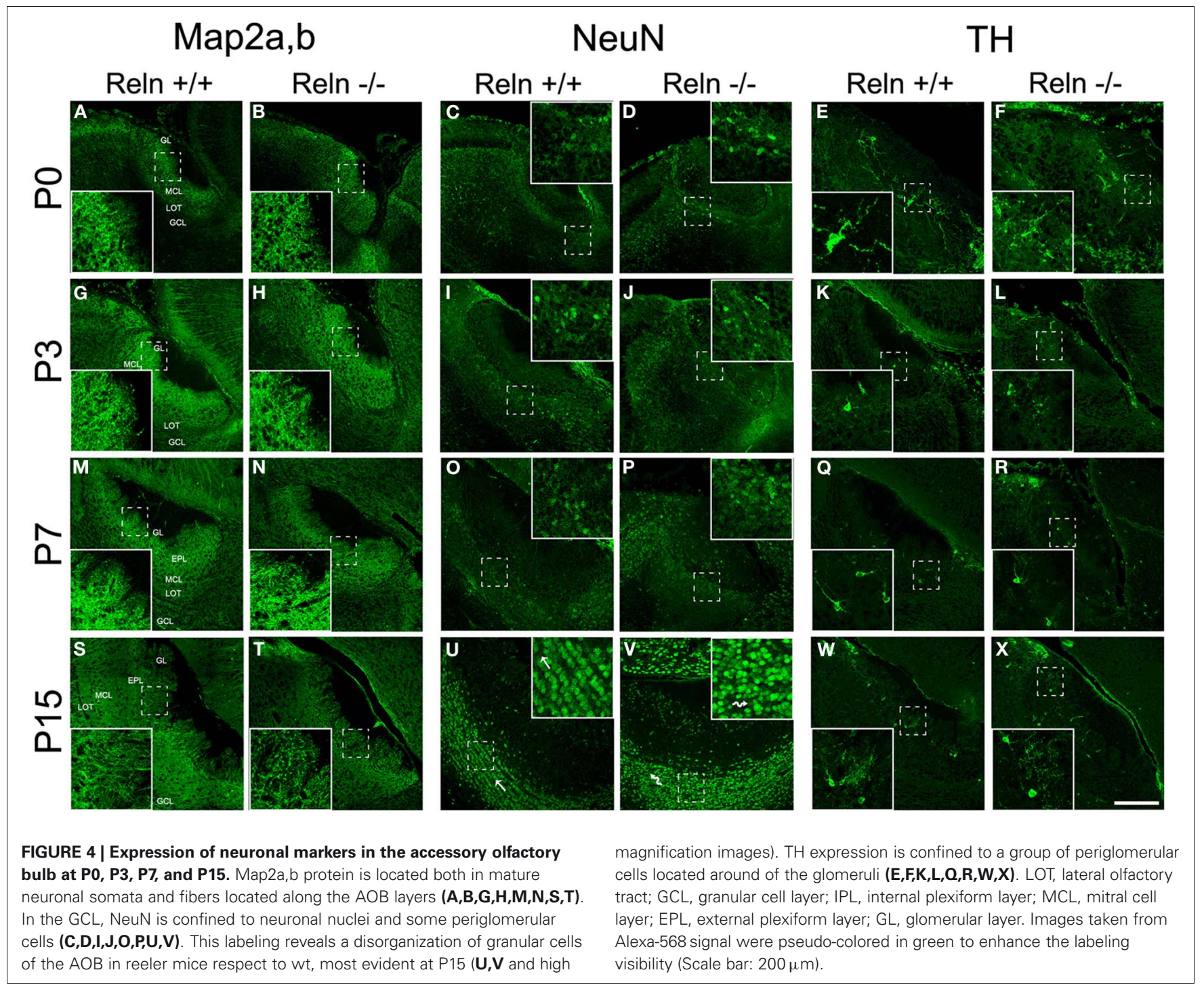


AOB layers (Figures $\mathbf{5 G}, \mathbf{H}, \mathbf{M}, \mathbf{N}$ ), although mainly confined to the periglomerular regions at P15 (Figures 5S,T). The absence of Reln did not affect the RC2 expression. In relation to the astrocyte marker, in both strains, GFAP expression appeared restricted to the glia limitans at P0-P3 (Figures 5C,D,I,J). From P7, GFAP labeling extended to the rest of the AOB layers (Figures 5O,P) and it was expressed throughout $\mathrm{AOB}$ parenchyma at P15 (Figures 5U,V). RIP, antibody that recognizes a CNPase specific of oligodendrocytes, showed weak staining in the non-myelin oligodendrocytes at P0-P3 mostly in the LOT region (Figures 5E,F,K,L). From P7 the labeling was restricted to both myelin sheets of the LOT (Figures 5Q,R) and some myelin fibers crossing the GCL at P15 (Figures 5W,X arrows). Labeling of GFAP and RIP was indistinguishable between $w t$ and reeler mice.

\section{DISCUSSION}

The $\mathrm{AOB}$ is the CNS structure that receives and integrates the olfactory information from vomeronasal sensory neurons.
Since only scattered information is available regarding AOB layering, and because some of it is controversial (Hinds, 1968; Jimenez et al., 2000; Salazar et al., 2006), we first established the prenatal sequence of this process. Then we compared this developmental layer arrangement with that occurring in the MOB. Moreover, we analyzed some molecular features of the AOB as well as the effect of the lack of Reln, defined as a key molecule involved in several developmental processes of the CNS. To study how Reln affects the anatomical characteristics of the $\mathrm{AOB}$, we used reeler mutants to study the effects of its functional absence.

In the present study, we schematized the layer development of $\mathrm{AOB}$ over the course of the embryonic mouse development. Although the mitral/tufted cell generation in the AOB begins earlier than in MOB (Hinds, 1968; Jimenez et al., 2000), in both structures a homogeneous population of cells surrounding a thick ventricular layer (VZ) was present at E10-E11. However, layer segregation occurs earlier in the MOB than in the AOB (E12-E15). Subsequent developmental changes occurred

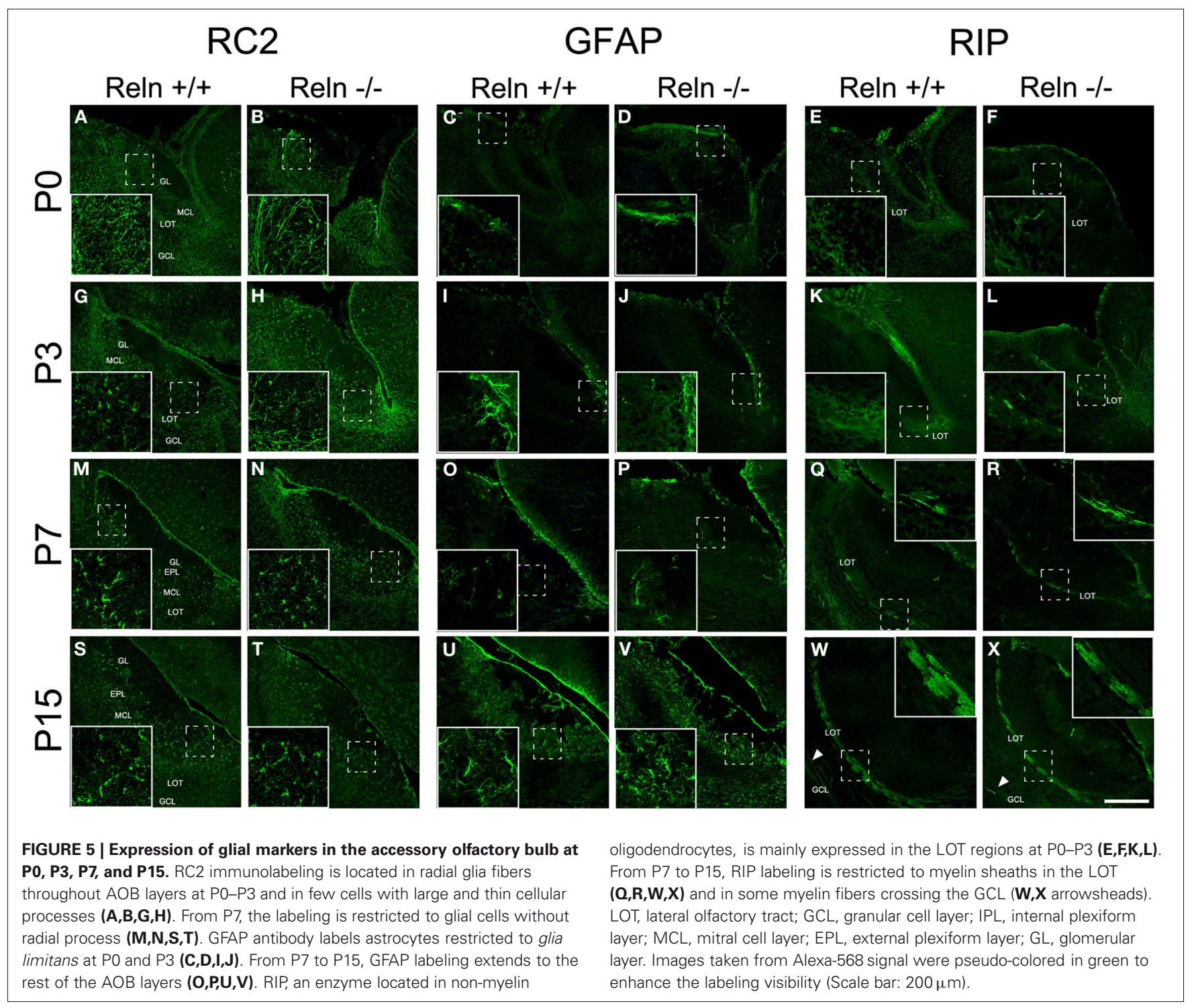


concurrently in both bulbs (Salazar et al., 2006), from poorly defined strata to well-defined layers. Although an external, mitral/tufted cell, internal plexiform, and granule cell layers are evident in the $\mathrm{AOB}$, they are less distinct than in the MOB. These layers were grouped into the external and internal cell layers by Larriva-Sahd (Larriva-Sahd, 2008).

On other hand, Reln is highly expressed in the olfactory system, including the olfactory bulb, vomeronasal organ, and vomeronasal nerves (Ikeda and Terashima, 1997; Alcantara et al., 1998; Teillon et al., 2003). In the OB, the absence of Reln affects the migration of neuroblasts from the rostral migratory stream and the layering of granular cells in the MOB (Hack et al., 2002; Martin-Lopez et al., 2011). This protein is a secreted extracellular matrix component that plays a crucial role in neuroblasts migration and cell settling in the developing brain, particularly for proper formation of laminar structures of mammalian brain (Caviness, Jr., 1976; Hack et al., 2002; Zhao et al., 2004). Our results showed that mice lacking functional Reln did not display significant alteration in the AOB cytoarchitecture, even when the GFAP expression in the hippocampus is altered in reeler animals (Zhao et al., 2004). However, we reported a disorganization of granular cells in reeler, as occurred in the MOB (Hack et al., 2002; Martin-Lopez et al., 2011), which probably indicates a role of Reln in the organization of the GCL.

\section{REFERENCES}

Alcantara, S., Ruiz, M., D’Arcangelo, G., Ezan, F., De, L. L., Curran, T., Sotelo, C., and Soriano, E. (1998). Regional and cellular patterns of reelin mRNA expression in the forebrain of the developing and adult mouse. J. Neurosci. 18, 7779-7799.

Altman, J. (1969). Autoradiographic and histological studies of postnatal neurogenesis. IV. Cell proliferation and migration in the anterior forebrain, with special reference to persisting neurogenesis in the olfactory bulb. J. Comp. Neurol. 137, 433-457.

Baum, M. J., and Kelliher, K. R. (2009). Complementary roles of the main and accessory olfactory systems in mammalian mate recognition. Annu. Rev. Physiol. 71, 141-160.

Blanchart, A., De Carlos, J. A., and Lopez-Mascaraque, L. (2006). Time frame of mitral cell development in the mice olfactory bulb. J. Comp. Neurol. 496, 529-543.

Blanchart, A., and Lopez-Mascaraque, L. (2011). From the periphery to the brain: wiring the olfactory system. Transl. Neurosci. 2, 293-309.

Blanchart, A., Romaguera, M., GarciaVerdugo, J. M., De Carlos, J. A., and Lopez-Mascaraque, L. (2008). Synaptogenesis in the mouse olfactory bulb during glomerulus development. Eur. J. Neurosci. 27, 2838-2846.

Caviness, V. S. Jr. (1976). Patterns of cell and fiber distribution in the neocortex of the reeler mutant mouse. J. Comp. Neurol. 170, 435-447.

D’Arcangelo, G., Miao, G. G., Chen, S. C., Soares, H. D., Morgan, J. I., and Curran, T. (1995). A protein related to extracellular matrix proteins deleted in the mouse mutant reeler. Nature 374 , 719-723.

Hack, I., Bancila, M., Loulier, K., Carroll, P., and Cremer, H. (2002). Reelin is a detachment signal in tangential chain-migration durNeurosci. 5, 939-945.

Hinds, J. W. (1968). Autoradiographic study of histogenesis in the mouse olfactory bulb. I. Time of origin of neurons and neuroglia. J. Comp. Neurol. 134, 287-304.

Honda, T., Kobayashi, K., Mikoshiba, K., and Nakajima, K. (2011). Regulation of cortical neuron migration by the Reelin signaling pathway. Neurochem. Res. 36, 1270-1279.

Howell, B. W., Hawkes, R., Soriano, P., and Cooper, J. A. (1997). Neuronal position in the developing brain is regulated by mouse disabled- 1 . Nature 389, 733-737.

Ikeda, Y., and Terashima, T. (1997). Expression of reelin, the gene responsible for the reeler mutation, in embryonic development and adulthood in the mouse. Dev. Dyn. $210,157-172$. ing postnatal neurogenesis. Nat.

Similarly, although the AOB and vomeronasal organ showed a high expression of Reln (Teillon et al., 2003) it appears that Reln does not have an axon guidance role in this connection, since there were none differences in the external layers of the $\mathrm{AOB}$ between $w t$ and reeler animals. As a whole, this strongly suggests that Reln does not provide guidance cues to targeting of the vomeronasal axons.

Furthermore, we described some anatomical features of the AOB using several neuronal and glial markers, which showed similar phenotypes to that observed in the MOB (Martin-Lopez et al., 2011). Among the neuronal markers, the expression of calbindin revealed few cells in the postnatal $\mathrm{AOB}$ as previously reported (Jia and Halpern, 2003; Kosaka and Kosaka, 2010).

In summary, our data provides new insights into the layering, organization, and the different cellular phenotypes in the AOB. Similar cytoarchitectonic features in the AOB were detected in the $\mathrm{AOB}$ and the MOB. Additionally, analysis of Reln mutants (reeler) mice revealed a disruption in the organization of granular cells.

\section{ACKNOWLEDGMENTS}

The authors are grateful to Sandra Rodriguez for her excellent technical assistance. This work was supported by Research grant BFU2010-15564 from Spanish Ministry of Economy and Competitiveness (MINECO).

Jia, C., and Halpern, M. (2003). Calbindin D28K immunoreactive neurons in vomeronasal organ and their projections to the accessory olfactory bulb in the rat. Brain Res. 977, 261-269.

Jimenez, D., Garcia, C., De, C. F. Chedotal, A., Sotelo, C., De Carlos, J. A., Valverde, F., and LopezMascaraque, L. (2000). Evidence for intrinsic development of olfactory structures in Pax-6 mutant mice. J. Comp. Neurol. 428, 511-526.

Kosaka, T., and Kosaka, K. (2010). Heterogeneity of calbindincontaining neurons in the mouse main olfactory bulb: I. General description. Neurosci. Res. 67 275-292.

Larriva-Sahd, J. (2008). The accessory olfactory bulb in the adult rat: a cytological study of its cell types, neuropil, neuronal modules, and interactions with the main olfactory system. J. Comp. Neurol. 510, 309-350.

Lois, C., and Alvarez-Buylla, A. (1994) Long-distance neuronal migration in the adult mammalian brain. Science 264, 1145-1148.

Lopez-Mascaraque, L., and De Castro, F. (2002). The olfactory bulb as an independent developmental domain. Cell Death Differ. 9, 1279-1286.

Luo, M., Fee, M. S., and Katz, L C. (2003). Encoding pheromonal signals in the accessory olfactory bulb of behaving mice. Science 299, 1196-1201.

Martin-Lopez, E., Blanchart, A., De Carlos, J. A., and LopezMascaraque, L. (2011). Dabl (disable homolog-1) reelin adaptor protein is overexpressed in the olfactory bulb at early postnatal stages. PLoS ONE 6:e26673. doi: 10.1371/journal.pone.0026673

Meisami, E., and Bhatnagar, K. P. (1998). Structure and diversity in mammalian accessory olfactory bulb. Microsc. Res. Tech. 43, 476-499.

Meredith, M. (1991). Sensory processing in the main and accessory olfactory systems: comparisons and contrasts. J. Steroid Biochem. Mol. Biol. 39, 601-614.

Mori, K., von, C. H., and Yoshihara, Y. (2000). Zonal organization of the mammalian main and accessory olfactory systems. Philos. Trans. R. Soc. Lond. B Biol. Sci. 355, 1801-1812.

Oboti, L., Savalli, G., Giachino, C., De, M. S., Panzica, G. C., Fasolo, A., and Peretto, P. (2009). Integration and sensory experience-dependent survival of newly-generated neurons in the accessory olfactory bulb of female mice. Eur. J. Neurosci. 29, 679-692.

Peretto, P., Giachino, C., Panzica, G. C., and Fasolo, A. (2001). Sexually dimorphic neurogenesis is topographically matched with the 
anterior accessory olfactory bulb of the adult rat. Cell Tissue Res. 306, 385-389.

Ramon y Cajal, S. (1901). Textura del lóbulo olfativo accesorio. Trab. Lab. Invest. Biol. 1, 141-149.

Restrepo, D., Arellano, J., Oliva, A. M., Schaefer, M. L., and Lin, W. (2004). Emerging views on the distinct but related roles of the main and accessory olfactory systems in responsiveness to chemosensory signals in mice. Horm. Behav. 46, 247-256.

Rice, D. S., Sheldon, M., D’Arcangelo, G., Nakajima, K., Goldowitz, D., and Curran, T. (1998). Disabled1 acts downstream of Reelin in a signaling pathway that controls laminar organization in the mammalian brain. Development 125 , 3719-3729.
Salazar, I., Sanchez-Quinteiro, P., Cifuentes, J. M., and Fernandez De, T. P. (2006). General organization of the perinatal and adult accessory olfactory bulb in mice. Anat. Rec. A Discov. Mol. Cell. Evol. Biol. 288, 1009-1025.

Schiffmann, S. N., Bernier, B., and Goffinet, A. M. (1997). Reelin mRNA expression during mouse brain development. Eur. J. Neurosci. 9, 1055-1071.

Shepherd, G. M. (2005). Perception without a thalamus how does olfaction do it? Neuron 46, 166-168.

Teillon, S. M., Yiu, G., and Walsh, C. A. (2003). Reelin is expressed in the accessory olfactory system, but is not a guidance cue for vomeronasal axons. Brain Res. Dev. Brain Res. 140, 303-307.
Wyss, J. M., Stanfield, B. B., and Cowan, W. M. (1980). Structural abnormalities in the olfactory bulb of the Reeler mouse. Brain Res. 188, 566-571.

Xu, F., Schaefer, M., Kida, I., Schafer, J., Liu, N., Rothman, D. L., Hyder, F., Restrepo, D., and Shepherd, G. M. (2005). Simultaneous activation of mouse main and accessory olfactory bulbs by odors or pheromones. J. Comp. Neurol. 489, 491-500.

Zhao, S., Chai, X., Forster, E., and Frotscher, M. (2004). Reelin is a positional signal for the lamination of dentate granule cells. Development 131, 5117-5125.

Conflict of Interest Statement: The authors declare that the research was conducted in the absence of any commercial or financial relationships that could be construed as a potentia conflict of interest.

Received: 13 March 2012; paper pending published: 31 March 2012; accepted: 03 May 2012; published online: 22 May 2012.

Citation: Martín-López E, Corona R and López-Mascaraque L (2012) Postnatal characterization of cells in the accessory olfactory bulb of wild type and reeler mice. Front. Neuroanat. 6:15. doi: 10.3389/fnana.2012.00015

Copyright (c) 2012 Martín-López, Corona and López-Mascaraque. This is an open-access article distributed under the terms of the Creative Commons Attribution Non Commercial License, which permits non-commercial use, distribution, and reproduction in other forums, provided the original authors and source are credited. 